\title{
Kicz i Holokaust, czyli pedagogiczny wymiar ekspozycji muzealnych
}

\begin{abstract}
Łatwiej [...] wyznaczyć granicę na pustyni w czasie zamieci lub na wzburzonym oceanie niż granice kiczu. Łatwiej nam będzie odpowiedzieć, do których kiczów podchodzimy z sympatia, które budza dezaprobatę, a które sa nam potrzebne wytacznie jako punkt odniesienia, gdy mówimy, że coś wygląda jarmarcznie, odpustowo lub tandetnie ${ }^{1}$.
\end{abstract}

Historia terminu „kicz” zaczęła się w latach sześćdziesiątych XIX w. Termin pochodzi od niemieckiego rzeczownika Kitsch, oznaczającego tanie, niskiej jakości malarstwo, oraz od czasownika verkitschen, w znaczeniu drobnego, oszukańczego handlu². Oczywiście od tamtych czasów znaczenie pojęcia uległo modyfikacjom, pozostając jednak określeniem silnie wartościującym i pejoratywnym. Paweł Beylin twierdzi, że kicz nigdy nie występuje w charakterze określenia estetycznie pozytywnego ${ }^{3}$.

Gruntowną, strukturalną analizę kategorii przeprowadził w latach siedemdziesiątych ubiegłego wieku Abraham Moles, wyróżniając pięć głównych zasad kiczu: zasadę niedostosowania (odchylenie w stosunku do funkcji, którą przedmiot powinien pełnić), zasadę kumulacji (nadmiernego gromadzenia, przerostu środków), zasadę synestezyjnej percepcji (angażowanie jak największej liczby zmysłów), zasadę przeciętności (nakierowanie na odbiorcę masowego) oraz zasadę komfortu (wywoływanie łatwej akceptacji i postawy komfortu) ${ }^{4}$. Oczywiście w podobnych rozważaniach chodzi o tradycyjne, przedmodernistyczne rozumienie dzieła sztuki, przełom modernistyczny dokonał bowiem przewartościowań i zakwestionował tradycyjne kryteria smaku estetycznego i tradycyjny warsztat. Na czele hierarchii

${ }^{1}$ M. Sosenko, Granice kiczu. Teoria i praktyka [w:] Kicz w kulturze, red. M. Fiderkiewicz, Katowice 2006, s. 149.

${ }^{2}$ C. Robotycki, Kicz - „kilka myśli... co nie nowe” [w:] Kicz w kulturze, op. cit., s. 15.

${ }^{3}$ P. Beylin, Kicz jako zjawisko estetyczne i pozaestetyczne [w:] idem, Autentyczność i kicze, Warszawa 1975, s. 179.

${ }^{4}$ A. Moles, Kicz czyli sztuka szczęścia. Studium o psychologii kiczu, przeł. A. Szczepańska, E. Wende, Warszawa 1978, s. 76-80. 
wartości pojawiło się nowatorstwo rozumiane absolutystycznie, tzn. bez związku z tradycyjnym rzemiosłem artystycznym ${ }^{5}$.

Współcześnie sytuacja jest jeszcze bardziej skomplikowana, a kicz, jak pisze Czesław Robotycki, stał się mało precyzyjnym terminem związanym z szeroko pojętą sztuką; bywa czasami określeniem „anty-sztuki”, ale dla wielu w modnej aktualnie przyzwalającej atmosferze intelektualnej w ogóle stracił rację bytu ${ }^{6}$. Ową „atmosferą intelektualną” jest oczywiście postmodernizm, który „szczególny nacisk kładzie [...] na zatarcie różnic pomiędzy sztuką i codziennym życiem, na zanik różnic pomiędzy sztuką wysokoartystyczną z jednej strony i kulturą masową czy popularną z drugiej, na powszechny bezład stylistyczny oraz ludyczne pomieszanie kodów"7.

W związku z wieloznacznością i nieokreślonością terminu należy za każdym razem precyzować, co w danym przypadku rozumiemy pod pojęciem kiczu. Aby jednak zdefiniować go na potrzeby niniejszego tekstu, muszę poświęcić kilka zdań samej instytucji muzeum publicznego. Odnalezienie elementów kiczu w ekspozycjach wydaje się już na pierwszy rzut oka zadaniem trudnym, przede wszystkim ze względu na to, że muzeum publiczne, którego narodziny przypadają na koniec osiemnastego stulecia, od samego początku zostało ukształtowane jako instytucja o dwóch funkcjach - wydawałoby się jak najdalszych od zjawiska kiczu: elitarnej świątyni sztuki i utylitarnego instrumentu demokratycznej edukacji. Muzeum publiczne, jak pisze Tony Bennett, zaczęło traktować społeczeństwo jako obiekt reform, rozwijając rozmaite technologie wymagające zmiany norm zachowania. Osiagano to przez reguły bezpośrednie, typu zakaz jedzenia i picia czy dotykania eksponatów bądź nakaz odpowiedniego ubioru, co powodowało, że chociaż w teorii muzeum było otwarte dla wszystkich, to nieformalnie istniała dyskryminacja i wykluczenie. To, co ważniejsze jednak, to konstytuowanie się muzeum jako przestrzeni emulacji (naśladownictwa), w której klasie robotniczej zezwolono mieszać się z klasą średnią i uczyć się nowych form zachowania przez naśladownictwo. Oferując przestrzeń, którą Bennett nazywa „nadzorowanym dostosowaniem się” (supervised conformity), muzeum oferowało kontekst, w którym nowe formy zachowania uwewnętrzniały się i stawały samodziałającymi imperatywami (self-acting imperatives). Im bardziej wycofywano ze sceny publicznej procesy karania, tym bardziej postrzegano muzea jako instrument obywatelskiej edukacji. Wizyta w muzeum - dawniej i teraz - to nie tylko patrzenie i nauka, to również ćwiczenie obywatelskości ${ }^{8}$.

Z drugiej strony chodziło również o to, by pokazać, że cywilizacje posiadające najbardziej kunsztowne obiekty są najbardziej zaawansowane. Michael J. Ettema,

${ }^{5}$ J. Tarnowski, Aksjologiczna definicja kiczu i zwiąane z nią trudności [w:] Kicz, tandeta, jarmarczność w kulturze masowej XX wieku, red. L. Rożek, Częstochowa 2000, s. 15-16.

${ }^{6}$ C. Robotycki, op. cit., s. 15.

${ }^{7}$ M. Featherstone, Postmodernizm i estetyzacja życia codziennego, przeł. P. Czapliński, J. Lang [w:] Postmodernizm. Antologia przekładów, red. R. Nycz, Kraków 1997, s. 302.

${ }^{8}$ T. Bennett, The Birth of the Museum. History, theory, politics, London - New York 1995, s. $90-102$. 
pisząc o dziewiętnastowiecznych ekspozycjach, zaznacza, że poprzez wystawianie obiektów pochodzących z różnych kultur uczyły hierarchicznego pojmowania rozwoju kulturowego i materializmu. Łączyły obiekty z systemem wartości, który wspierał idee technologicznego rozwoju, indywidualizmu i estetyki. Te wartości uważano za podstawę nowoczesnej cywilizacji. Dodatkowo, wskazując na wartość obiektów, wspierały potrzebę rosnącej konsumpcji. Oczywiście próbowały to robić w obrębie estetycznego, historycznego lub naukowego dyskursu w celu reformowania klasy robotniczej, ale imperatyw ekonomiczny był tu wyraźnie widoczny ${ }^{9}$. Najważniejsze jednak w tym okresie było to, że muzea stały się częścią kultury wizualnej, kultury „patrzenia” istotnej zarówno dla kapitalizmu, jak i dla nowoczesnego życia miejskiego.

Muzea nie mogą być jednak definiowane wyłącznie poprzez swoje związki z różnymi formami racjonalności i władzy. Nie znaczy to, że takie zależności nie istnieją, ale muszą być rozpatrywane wraz z siłami wobec siebie przeciwnymi, takimi jak kultura popularna, praktyki konsumpcji czy życie ulicy. Andrea Witcomb pisze, że muzea zawsze żywo reagowały na zjawiska pozostające poza ich kontrolą i były zaangażowane w dialog ze swą publicznością. Badaczka potwierdza, że dziewiętnastowieczne muzea otwarcie przyznawały się do intencji obywatelskiej edukacji (civic reform) oraz że muzea współczesne nadal wierzą w wypełnianie tej misji, chociaż coraz trudniej im ją realizować. Przywołuje jednak związek dziewiętnastowiecznych wystaw z międzynarodowymi targami i domami towarowy$\mathrm{mi}^{10}$. Międzynarodowe wystawy tworzyły nowoczesny kosmopolityzm rodzący się na zatłoczonych ulicach, gdzie świat przedstawiony był w miniaturze. Według krytyków takich jak Bennett przestrzeń tę należałoby interpretować w obrębie metafory postępu z podtekstem rasistowskim i nacjonalistycznym, ale inni, jak Witcomb, sugerują, że wystawy wywoływały uczucia inne niż tylko duma narodowa i rasowa - jak przyjemność i ekscytację - i zapewniały kontakt z egzotyką dający obietnicę rozrywki. Intensywność tych uczuć miała więcej wspólnego z kulturą popularną, która karmi podstawowe instynkty, niż z bardziej abstrakcyjnymi, moralnymi wartościami kultury wysokiej zwykle kojarzonej z instytucją muzeum ${ }^{11}$. Związek muzeum z kulturą popularną/masową, konsumpcją i ekonomią widoczny jest po dziś dzień w metaforze „muzeum - domu towarowego” przeciwstawianej metaforze „muzeum - katedry”, każda z nich pociąga za sobą bowiem odmienny stosunek do artefaktów i inne widzenie przeszłości ${ }^{12}$. W obu jednak przypadkach

${ }^{9}$ M.J. Ettema, History Museums and the Culture of Materialism [w:] Past Meets Present. Essays about Historic Interpretation and Public Audiences, red. J. Blatti, Washington D.C. 1987, s. 62-85.

${ }^{10}$ A. Witcomb, Re-Imagining the Museum: Beyond the Mausoleum, London - New York 2003, s. 5.

${ }^{11}$ Ibidem, s. 19.

${ }^{12}$ A. Radley, Boredom, fascination and morality: reflections upon the experience of museum visiting [w:] Museum Languages: Objects and Texts, red. G. Kavanagh, Leicester - London New York 1991, s. 69-72. 
muzea funkcjonują w społeczeństwie jako instytucje obdarzone autorytetem, a treści przez nie krzewione mają status prawd obiektywnych i uniwersalnych. Kicz zdefiniowany w jeden $\mathrm{z}$ powyższych sposobów nie istnieje w przestrzeni muzealnej, która jest nobilitująca i na swój sposób sakralna - mimo że świecka. Obiekty wystawiane w ramach kolekcji muzealnych są usunięte ze świata handlu i używając terminologii Igora Kopytoffa, „ujednostkowione”13. Muzeum jest zatem miejscem, w którym dokonuje się proces „ujednostkowienia” (singularization) obiektu i w którym wszystkie przedmioty są wyłączone z codziennego życia, co nadaje im szczególne znaczenie. W konsekwencji obiekt, który w innych kontekstach mógłby zostać oceniony jako kicz, tutaj - poprzez sam fakt bycia częścią kolekcji muzealnej - nabiera zupełnie innego wymiaru, staje się „ujednostkowionym” obiektem muzealnym, przedmiotem poznania intelektualnego (a nie tylko przeżycia estetycznego) interpretowanym w zupełnie innych kategoriach. Relacje, jakie nawiązuje z innymi przedmiotami znajdującymi się w danej kolekcji, są już zupełnie nowego rodzaju, gdyż definiuje je kontekst muzealny.

W muzeach historycznych (a takimi są muzea Holokaustu) tym bardziej nie możemy mówić o kiczu w sensie artystycznym, warsztatowym czy estetycznym, gdyż artefakty spełniają tam całkowicie inne funkcje. Hierarchia ważności obiektów muzealnych zależy w tym przypadku od nadanej im (przez kuratorów) wartości związanej z ich znaczeniem intelektualnym i potencjałem interpretacyjnym. Najogólniej rzecz ujmując, stają się źródłami historycznymi i jako takie nie są oceniane w kategoriach kiczu.

Mówienie o kiczu w muzeum historycznym możliwe jest zatem, moim zdaniem, jedynie wtedy, gdy zdefiniujemy ten termin jako pewien sposób przekazywania wiedzy nastawiony na wywołanie w widzu określonych, najczęściej łatwych - w sensie nieskomplikowania - emocji. Taki sposób rozumienia zjawiska jest już oczywiście znany. Wspomniany powyżej Abraham Moles łączył kategorię kiczu głównie z dziewiętnastowieczną kulturą mieszczańską, gdzie miał on pełnić przede wszystkim funkcję dostarczania przyjemności ${ }^{14}$. Definiowanie kiczu jako dostarczyciela łatwej przyjemności zbliżone jest również do kategorii „estetyki” ludowej Pierre’a Bourdieau: „[...] ludowa publiczność” - pisze francuski badacz - „lubuje się w intrygach logicznie i chronologicznie nastawionych na happy end i lepiej »odnajduje się« w sytuacjach oraz postaciach zarysowanych prosto niż w postaciach i akcjach dwu-

${ }^{13}$ Kopytoff mówi również o „utowarowieniu” (commoditization) w odniesieniu do obiektu, który może być swobodnie wymieniany na rynku, ma wartość pieniężną i jest osiągalny dla wszystkich, których na to stać. Społeczeństwa wyodrębniają pewną część swego środowiska, naznaczając ją jako świętą. W ten sposób kultura gwarantuje pewnym rzeczom niebudzącą wątpliwości jednostkowość, przeciwstawia się utowarowieniu innych, a czasami to, co było już towarem, staje się z powrotem jednostkowe. W każdym społeczeństwie istnieją rzeczy publicznie wyłączone z procesu utowarowienia; zob. I. Kopytoff, Kulturowa biografia rzeczy - utowarowienie jako proces, przeł. E. Klekot [w:] Badanie kultury. Elementy teorii antropologicznej, red. M. Kempny, E. Nowicka, Warszawa 2005, s. 258.

${ }^{14}$ A. Moles, op. cit., s. 81. 
znacznych oraz symbolicznych"15. Mamy tu zatem do czynienia z pewnym - jak określiła to Elżbieta Anna Sekuła - powielaniem bezpiecznego etycznie i intelektualnie stereotypu ${ }^{16}$. Badaczka za Wojciechem Bursztą i Krzysztofem Piątkowskim określa kicz jako „pewien sposób ujmowania i wyrażania jakichś treści. Oczywiście w sposób naiwny, przesłodzony, schematyczny; zastosowano przy tym złą manierę, zły topos, kiepsko rzecz wykonano"17. Elementy kiczu definiowanego w taki sposób można odnaleźć w muzeach Holokaustu, co postaram się wykazać na przykładzie United States Holocaust Memorial Museum w Waszyngtonie.

Ekspozycje holokaustowe mają za zadanie pokazać przebieg i skutki procesu, w wyniku którego śmierć poniosło miliony ludzi. Śmierć okrutną, połączoną z dehumanizacją, przemocą i terrorem. Moja analiza nie będzie dotyczyć samego zjawiska Zagłady, czyli Holokaustu jako procesu historycznego ${ }^{18}$, ale wyłącznie jego reprezentacji w formie wystawy muzealnej.

Muzealne reprezentacje Holokaustu należą do tak zwanych „ekspozycji trudnych”, czyli takich, które mają do zaprezentowania ciężki i przygniatający prze$\mathrm{kaz}^{19}$. Problematyczna jest nie tylko reprezentacja traumatycznego doświadczenia innych, ale samo spotkanie z odmiennością tej wiedzy (otherness of knowledge). Chodzi tu o momenty, w których wiedza jawi się jako skrajnie inna oraz niezrozumiała, gdy stajemy w obliczu granic możliwości, a nawet granic chęci rozumienia. W momencie zetknięcia z taką wiedzą (ekspozycja) doświadczamy częściowego rozumienia pomieszanego z zakłopotaniem, dezorientacją; strach i cierpienie innych miesza się z naszą obawą i niepokojem. Takie momenty mogą uruchamiać mechanizmy samoobrony, polegające na zdystansowaniu się od doświadczenia innych czy deprecjonowaniu tego doświadczenia. Pojęcie „trudnej” wystawy odnosi się także do takiego aspektu doświadczenia odwiedzających, który jest znaczącym wyzwaniem dla ich interpretacyjnych zdolności. Następuje to wtedy, gdy wystawa nie dostarcza prostego zakończenia historii, w zamian za to prezentując wielość perspektyw. Niedokończone i niejednoznaczne historie mogą być postrzegane jako frustrujące, wymagają od widza zaangażowania, konfrontacji z własnymi oczeki-

${ }^{15}$ P. Bourdieu, Dystynkcja. Społeczna krytyka władzy sadzenia, przeł. P. Biłos, Warszawa 2005, s. 46.

${ }^{16}$ E.A. Sekuła, Piramida w cieniu palmy - o przaśnym Paryżu na Górnym Ślasku [w:] Kicz w kulturze, op. cit., s. 78.

${ }^{17}$ W. Burszta, K. Piątkowski, O czym opowiada antropologiczna opowieść, Warszawa 1994, s. 116, cyt. za: E.A. Sekuła, op. cit., s. 71.

${ }^{18}$ Warto w tym miejscu przypomnieć, że według Stanisława Lema sam nazizm opierał się na etyce zła i estetyce kiczu. Kicz według pisarza przejawiał się zarówno w monumentalnej architekturze III Rzeszy, jak i „przesączył się do obozów, na place apelowe, bo się wkradł w dramaturgię taśmowego mordu, choć nikt tego nie zamierzył”. Kiczowaci byli naziści wcielający się w rolę Boga Ojca w „sztuce, inscenizowanej w obskurnych dekoracjach baraków i zasieków”, niestety z „zawsze autentycznym epilogiem”; zob. S. Lem, Prowokacja, Kraków 2003, s. 294-296.

${ }^{19}$ J. Bonnell, R.I. Simon, „Difficult” exhibitions and intimate encounters, „Museum and Society", czerwiec 2007, nr 5 (2), s. 65-85. 
waniami związanymi z określonym sposobem „opowiadania historii”. Trudne ekspozycje to także te, które wywołują negatywne emocje, nieprzyjemne i kłopotliwe uczucia żalu, złości, wstydu czy grozy. Mogą spowodować niepokój towarzyszący uczuciu identyfikacji z ofiarami przemocy czy potencjalną powtórną traumatyzację u tych, którzy w przeszłości takimi ofiarami byli, co czasami może prowadzić do oskarżeń, że muzeum wykorzystuje ból innych, epatuje voyerystycznymi, sensacyjnymi obrazami przemocy i cierpienia ${ }^{20}$.

„Trudność” ekspozycji nie zwalnia jednak ich twórców od stosowania pewnych podstawowych reguł, które - według Piotra Ungera - pozostają wspólne dla wszystkich muzeów historycznych. Przede wszystkim wystawa musi być zgodna z najnowszymi ustaleniami historii jako nauki: powinna odzwierciedlać konkretne fakty i zjawiska historyczne oraz podstawowe założenia metodologiczne historii. Wymóg naukowości ekspozycji pociąga za sobą dalsze konsekwencje, między innymi konieczność takiego ukazywania zbiorów, żeby służyły logicznie uporządkowanemu przekazywaniu wiedzy, by systematyzowały oraz porządkowały wiadomości, a także dostarczały wrażeń emocjonalnych. Konsekwencją realizacji tego założenia jest taka konstrukcja scenariusza oraz pogrupowanie i rozmieszczenie eksponatów, żeby tworzyły zwartą i przejrzystą całość, w której prezentowane zjawiska pozostają w związkach przyczynowo-skutkowych i czasowo-przestrzennych oraz w której tematy drugoplanowe, podrzędne wypływają z zasadniczego problemu ekspozycji ${ }^{21}$. Mimo obowiązujących zasad ogólnych każde wydarzenie historyczne (włączając w to masowe mordy) można przedstawić rozmaicie, w zależności od funkcji, jakie ma pełnić wystawa, oraz koncepcji etycznych i estetycznych przyjętych przez twórców ekspozycji.

Koncepcję zastosowaną przez twórców ekspozycji Muzeum Holokaustu w Waszyngtonie nazwałam koncepcją „śmierci wyobrażonej” (w odróżnieniu od śmierci „rzeczywistej” i symbolicznej - koncepcji stosowanych w innych muzeach, o których w tym miejscu nie będę pisać). Koncepcja „śmierci wyobrażonej” wydaje się bliska pewnego rodzaju inscenizacji, która - poprzez użycie odpowiednich artefaktów - kreuje atmosferę mającą „przenieść” widza siłą jego wyobraźni w inny czas i miejsce. Jeden z designerów wystawy Ralph Appelbaum wyraził tę ideę explicite: „jeśli zmusimy ludzi do przejścia z normalnego życia, jakie prowadzą, do gett, z gett do pociągów, z pociągów do obozów, na terenie obozów odpowiednimi drogami, aż do samego końca... jeśli odwiedzający będą mogli przebyć tę samą podróż, zrozumieją historię, ponieważ jej doświadczą"22. Ekspozycja ma zatem za zadanie

${ }^{20}$ Wystawę „trudną” należy odróżnić od wystawy „kontrowersyjnej”, która, przykładowo, będzie stawiać cierpienie jednych nad cierpieniem innych, J. Bonnell, R. Simon, op. cit., s. 66.

${ }^{21}$ P. Unger, Muzea w nauczaniu historii, Warszawa 1988, s. 18. Regułę tę Unger nazwał zasadą systematyczności; zob. też P. Unger, Jak budować ekspozycję muzealna, żeby odpowiadała ona potrzebom szkoty $i$ wymogom dydaktyki [w:] Muzea w procesie wychowywania młodzieży, red. K. Nowiński, Warszawa 1977.

${ }^{22}$ Cyt. za: T. Cole, Selling the Holocaust. From Auschwitz to Schindler. How History Is Bought, Packed And Sold, New York 2000, s. 161. 
wywołać w publiczności poczucie doświadczenia przeszłości i w konsekwencji - jej zrozumienia.

W celu przekształcenia wielowymiarowego wydarzenia (a w praktyce wielości wydarzeń i procesów historycznych), którym była Zagłada, w jedną linię narracyjną rozpatrywano trzy strukturalne możliwości: chronologiczną (rozwój wydarzeń w czasie), geograficzną (historia poszczególnych krajów) lub linearną (w obrębie głównych tematów). Połączono wszystkie trzy drogi: okres od 1933 do 1939 r. ma układ chronologiczny. W przypadku wydarzeń samego Holokaustu twórcy uznali chronologię za nieadekwatną i wybrali analizę poszczególnych etapów ostatecznego rozwiązania: getto, deportacje, obozy koncentracyjne, obozy śmierci. W ostatniej części następuje powrót do chronologii oraz trzy wystawy tematyczne: ratowanie Żydów przez nie-Żydów, zbrojny i duchowy opór oraz los dzieci²3.

Punktem kulminacyjnym wystawy jest „Świat obozów koncentracyjnych” (The Concentration Camp Universe) wykreowany za pomocą autentycznych artefaktów oraz replik przedmiotów pochodzących z różnych obozów i ustawionych tak, by pasowały do ogólnej wizji twórców. Zmierzając do tej części wystawy, najpierw mijamy wagon - centralny symbol deportacji - wypożyczony z Treblinki i z napisu dowiadujemy się, że jest to „typ wagonu” wykorzystywanego do przewożenia Żydów do obozów. Następnie przechodzimy przez bramę z napisem Arbeit macht frei replika bramy z Auschwitz I - i kierujemy się w stronę rekonstrukcji drewnianych baraków z Auschwitz II-Birkenau, potem oglądamy komory gazowe z Auschwitz I oraz krematorium, które jest z kolei repliką krematorium z obozu w Mauthausen. Możemy obejrzeć również oryginalne buty pozostałe po więźniach obozu na Majdanku oraz olbrzymie zdjęcie włosów ofiar Auschwitz. Sam proces mordowania przedstawiony jest za pomocą gipsowej makiety wykonanej przez Mieczysława Stobierskiego. Model pokazuje moment śmierci ludzi znajdujących się już w komorze gazowej, działalność Sonderkommando i kremację ciał ${ }^{24}$. W takiej formie „Świat obozów koncentracyjnych” jest kreacją i symulacją podważającą różnicę pomiędzy tym, co „prawdziwe”, i tym co „fałszywe”, tym, co „rzeczywiste”, i tym, co „wyobrażone”, w celu przybliżenia odwiedzającym doświadczenia Zagłady. Zgodnie z klasyczną koncepcją Jeana Baudrillarda mamy tu do czynienia z podstawieniem „w miejsce rzeczywistości znaków rzeczywistości”, czyli z operacją, „gdzie zamiast realnego procesu na plan pierwszy wysuwa się jego operacyjny sobowtór, homeostatyczna maszyna znakotwórcza, bezgrzeszna, programowalna, która oferuje wszystkie znaki rzeczywistości i w krótkim zwarciu wszystkie jej perypetie"25. Auschwitz wykreowane w muzeum Holokaustu jest takim właśnie

${ }^{23}$ J. Weinberg, R. Elieli, The Holocaust Museum in Washington, New York 1995, s. 54.

${ }^{24}$ W Muzeum Auschwitz-Birkenau taka makieta, wykonana również przez Mieczysława Stobierskiego, znajduje się w bloku nr 4, na pierwszym piętrze.

${ }^{25}$ J. Baudrillard, Precesja symulakrów, przeł. T. Komendant [w:] Postmodernizm. Antologia przekładów, op. cit., s. 177, zob. też idem, Symulakry i symulacja, przeł. S. Królak, Warszawa 2005, s. 7. Więcej na ten temat pisałam w artykule Przedstawienia Holocaustu 
simulacrum - rzeczywistością nie tyle fałszywą (jak chciałby Omer Bartov²6), ile zastąpioną znakami rzeczywistości. Kicz i symulacje mogą uchodzić za zjawiska zbliżone z powodu cechującego je braku autentyczności, jednak teza taka byłaby, moim zdaniem, ryzykowna. Nie chodzi tu bowiem o nieudolne naśladownictwo (kicz), lecz o pewną fundamentalną relację rzeczywistości i jej przedstawienia (simulacrum), w której owo przedstawienie wyrasta poza rzeczywistość, wchłania ją. Tak rozumiane simulacrum stanowi jedną z najważniejszych kategorii kultury współczesnej. W przypadku ekspozycji w waszyngtońskim muzeum niepokoi mnie nie tyle stworzenie symulacji, ile założenie, że wystawa w takim kształcie odzwierciedla rzeczywisty horror obozów, podczas gdy mamy tam do czynienia jedynie z wystylizowaną wizją uniwersum koncentracyjnego, które w tej formie nigdy i nigdzie nie istniało. Wbrew intencjom Appelbauma nie odbywamy tej samej podróży, co deportowani Żydzi i nie doświadczamy ich losu, jesteśmy publicznością muzealną, a emocje towarzyszące zwiedzaniu nie są - bo być nie mogą traumatyczne.

Kolejne zagadnienie związane z koncepcją „śmierci wyobrażonej”, na które chciałabym zwrócić uwagę, wydaje się jeszcze wyraźniej łączyć ze zjawiskiem kiczu wedle podanej wyżej definicji. Na początek odwołam się raz jeszcze do słów Ralpha Appelbauma, według którego ekspozycje powinny być ekspresywne, by móc opowiedzieć historię w sposób świeży. „[...] mamy wybór” - twierdzi Appelbaum „między przedstawieniem opartym na fikcji, istnieje wiele tego typu przedstawień [...], i widowiskiem [entertainment] opartym na prawdziwych wydarzeniach, które czyni ludzi bardziej odpowiedzialnymi rodzicami i bardziej angażuje w sprawy społeczne"27. W muzeum Holokaustu mamy zatem do czynienia z pewnego rodzaju przedstawieniem bazującym na tak zwanych faktach historycznych, co ma sprawić, że historia będzie głęboko angażująca. Wybór takiej koncepcji obciążony jest jednak określonymi konsekwencjami, czego twórcy - wydaje się - byli nieświadomi. Otóż tego typu reprezentacja najprawdopodobniej zostanie przez widzów odczytana przez pryzmat estetyk, które już znają z podobnych przedstawień. Jedną z możliwości jest tutaj estetyka horroru, zgodnie ze słowami Philipa Gourevitcha szczególnie bliska amerykańskim odbiorcom. Gourevitch uznaje, że przemoc i groteska są zasadnicze dla amerykańskiej estetyki, a historia opowiedziana w muzeum

w muzeach. Próba porównania [w:] Pamięć i polityka historyczna, red. S.M. Nowinowski, J. Pomorski, R. Stobiecki, Łódź 2008, s. 157-174.

26 „Te »autentyczne« artefakty” - pisze Omer Bartov - „są powiązane z rzeczywistością Holokaustu nie bardziej niż rekonstrukcja osady purytańskiej w Nowej Anglii lub imitacja tradycyjnego gospodarstwa w Szwarcwaldzie; podobieństwo jest równie zwodnicze (i rozdzierające) co między męskim zakładem fryzjerskim a stertą butwiejących włosów ofiar w muzealnym magazynie”, O. Bartov, Murder in Our Midst. The Holocaust Industrial Killing and Representation, New York - Oxford 1996, s. 182.

${ }^{27}$ D. Garfield, The Next Thing Now: Designing the 21st-Century Museum (rozmowa z Ralphem Appelbaumem), „Museum News”, January/February 1996, s. 35. 
Holocaustu wpisuje się w nią swą przytłaczającą symboliką ${ }^{28}$. Nad tą tezą chciałabym się zatrzymać.

Horror filmowy (biorę pod uwagę film, gdyż muzea przynależą bardziej do strefy kultury wizualnej niż werbalnej) reprezentuje odwieczną walkę Dobra ze Złem, czyli treść wszystkich mitologii, a jego popularność można tłumaczyć zapotrzebowaniem widza na mit ${ }^{29}$. Definiowany jest głównie przez emocje, które wywołuje, czyli odbiegający od normy psychologiczny stan niepokoju, wzburzenia, lęku czy wstrętu ${ }^{30}$. Ten stan powodowany jest myślą o potworze (monster), który jest elementem zagrażającym i nieczystym (impure) - w tym sensie, że jest postrzegany jako obcy, nieznany, leżący poza kategoriami kulturowymi ${ }^{31}$. Głębokie struktury narracyjne, na których opierają się fabuły (plot) horrorów, są bardzo do siebie podobne (horrory różnią się od siebie tylko powierzchniowymi wariacjami). Noël Carroll określa je jako pełną fabułę odkrycia (complex discovery plot) i dzieli na cztery etapy (nie muszą występować wszystkie naraz, ale jest to pewien typ idealny): nadejście (onset), odkrycie/ujawnienie (discovery), potwierdzenie (confirmation) i konfrontacja (confrontation) ${ }^{32}$. Jednostka w horrorze nigdy nie jest wolna, lecz zawsze uwikłana w niebezpieczeństwo czyhające na zewnątrz lub czające się w niej samej ${ }^{33}$. Wewnątrz struktury narracyjnej horroru obowiązuje strategia polegająca na kumulacji szoku, czyli zasada locus horridus. Doświadczenie szoku anulowane jest przez powrót do akceptowanej normy społecznej. Funkcja semantyczna locus horridus jest stała - twierdzi Iwona Kolasińska: oznacza lęk i sygnalizuje, że „linia demarkacyjna dzieląca świat rzeczywisty od demonicznego jest łatwa do przesunięcia i naruszenia”34.

Rozpatrując wystawę muzealną przez pryzmat estetyki horroru, należy przede wszystkim zwrócić uwagę na podstawowe, jak się wydaje, zastrzeżenie. Otóż istnieją takie wydarzenia w świecie rzeczywistym, które - mimo nieobecności istot obcych/potworów - określamy mianem horroru. Nazistowskie ludobójstwo nader często bywa nazywane w ten sposób przez ocalałych, świadków czy badaczy zajmujących się nim jako zjawiskiem historycznym. Carroll w swej pracy o horrorze jako gatunku filmowym czyni również wyraźne rozróżnienie pomiędzy horrorem tzw.

${ }^{28}$ P. Gourevitch, Behold Now Behemoth. The Holocaust Memorial Museum: One More American Theme Park, „Harper’s Magazine”, July 1993, t. 287, nr 1718, s. 55-62.

${ }^{29}$ I. Kolasińska, Widz w tekście horroru: studium o gatunku [w:] Kino gatunków, red. A. Helman, „Zeszyty Naukowe Uniwersytetu Jagiellońskiego. Prace Historycznoliterackie”, zeszyt 75, Warszawa-Kraków 1991, s. 35.

${ }^{30}$ N. Carroll, The Philosophy of Horror Or Paradoxes of the Heart, London - New York 1990, s. 24.

${ }^{31}$ Ibidem, s. 35.

${ }^{32}$ Ibidem, s. 97-108. Dla Iwony Kolasińskiej ogólny schemat to: zainicjowanie niepokoju w ekspozycji filmu (zerwanie porządku), jego lokalizacja w „miejscu grozy” i anulowanie napięcia przez zaplanowanie racjonalnego porządku w jego zakończeniu, zob. I. Kolasińska, op. cit., s. 37.

${ }^{33}$ I. Kolasińska, op. cit., s. 36.

${ }^{34}$ Ibidem, s. 37, 38 i 44. 
naturalnym a horrorem-sztuką (art-horror) ${ }^{35}$. Jednak rozróżnienie to się zaciera, kiedy próbujemy horror naturalny w jakikolwiek sposób - werbalny czy wizualny przedstawić. Reprezentacja nie jest już wydarzeniem samym i można rozpatrywać ją pod kątem elementów retorycznych i estetycznych, które nieodzownie zawiera. Warto również pamiętać, że osobą odpowiedzialną za główne założenia ekspozycji w Muzeum Holokaustu w pierwszych etapach jej koncepcji i powstawania był Martin Smith, filmowiec dokumentalista. On sam używał określenia horror na opisanie zarówno wydarzeń, jak i ich reprezentacji: „Myślę, że nie możemy uniknąć patrzenia na najstraszniejszy materiał. [...] Jeśli nie umieścimy go na wystawie, pomniejszymy rozmiar horroru i znaczenie owego doświadczenia. [...] Jestem pewny, że cokolwiek byśmy zrobili, wiele osób poczuje się urażonych. Nie sądzę, że to wina instytucji, to wina samego wydarzenia"36.

Pod względem narracyjnym amerykańska wystawa wydaje się faktycznie zgodna z fabułą horroru: rozpoczyna się pojawieniem zła (rok 1933 - dojście nazistów do władzy), kończy konfrontacją i zwycięstwem (aliantów, a głównie Amerykanów). Zło, co prawda, pochodzi jak najbardziej z tego świata, ale warto pamiętać, że wielokrotnie próbowano interpretować Holokaust jako zjawisko całkowicie obce zachodniej cywilizacji, jako pewną wyrwę czy aberrację w kulturze. Za niezwykle szokujący locus horridus wystawy uznałabym znajdujące się w samym centrum ekspozycji, w pobliżu makiety Stobierskiego, dokumentalne zdjęcia pokazujące eksperymenty medyczne przeprowadzane przez nazistów na ludziach. Fotografie (pokazywane jako zmieniające się na dużych monitorach slajdy, ukryte przed oczami dzieci wysokimi ochronnymi barierami) są niezwykle drastyczne, pokazują zarówno żywe osoby w trakcie eksperymentów, jak i zwłoki (a także fragmenty zwłok) pozostałe po zabiegach. Groza, którą odczuwamy, patrząc na pokaz slajdów, jest spowodowana między innymi lękiem o własne ciało. Ma to zasadnicze znaczenie dla estetyki horroru. Kolasińska pisze: „Ciało cięte, okaleczone, deformowane, niszczone, chore, poddawane zabiegom chirurgicznym, transplantacji organów i biomedycznej analizie, to obrazy preferowane przez współczesne kino, ze względu na ich potencjalnie wstrząsający charakter. Horror współczesny ewokuje strach człowieka o własne ciało w sensie fizycznym i o sprawowanie kontroli nad nim”37. Powrót do „normalnego” świata i ostateczne zaakcentowanie zwycięstwa nad złem następuje z chwilą opuszczenia muzeum, kiedy odwiedzający znajdują się z powrotem w centrum waszyngtońskiego Mallu - w miejscu, z którego widać monumenty twórców amerykańskiej demokracji oraz Biały Dom i Kapitol. Ekspozycja, którą odwiedzający muzeum przed chwilą widzieli, wydaje się wręcz nierzeczywista, a zbrodnia niemożliwa do pojęcia - szczególnie tu, w Stanach Zjednoczonych.

Samo zastosowanie estetyki horroru w reprezentacji Holokaustu niekoniecznie musi być niepokojące czy kiczowate (chociaż horror tradycyjnie określany

\footnotetext{
${ }^{35}$ N. Carroll, op. cit., s. 35.

${ }^{36}$ Cyt. za: A. Liss, Trespassing Through Shadows. Memory, Photography and the Holocaust, Minneapolis-London 1998, s. 16.

${ }^{37}$ I. Kolasińska, op. cit., s. 42.
} 
jest gatunkiem filmowym „klasy B”). Nie można wszak przedstawić wydarzenia historycznego, nie wykorzystując którejś z dostępnych w kulturze retoryk/estetyk. Wybrano właśnie tę - zapewne instynktownie - bo bliska jest amerykańskiemu odbiorcy i wydaje się w sposób samoistny pasować do wydarzenia określanego jako horror naturalny. Niebezpieczeństwo tkwi w tym, że twórcy horrorów dostarczają widzowi szokujących przeżyć, by „zadośćuczynić ludzkiej potrzebie katharsis: widz pragnie bowiem bać się w kręgu fikcji po to, aby nie bać się w rzeczywistości. Potrzeba bycia straszonym wiąże się także $z$ pragnieniem obcowania $z$ »inną rzeczywistością", niedostępną lub zakazaną. Horror dostarcza zastępczego zaspokojenia ukrytych czy odrzuconych życzeń i pragnień widza przez ich symboliczne spełnienie na ekranie. Rekompensuje banalną »codzienność« widza przez przeżycie filmowego snu na jawie"38. Ten sposób reprezentacji byłby zatem pomyłką z punktu widzenia założeń twórców, wystawa nie byłaby bowiem dla nikogo lekcją ani odpowiedzialności, ani moralności, lecz doświadczeniem swoistego rodzaju suspensu, na dodatek z optymistycznym, mimo wszystko, zakończeniem (zamknięcie ekspozycji stanowi film skomponowany ze świadectw ocalałych, opowiadających o swoim ocaleniu i o oporze, zarówno zbrojnym, jak i duchowym).

Z powyższym zagadnieniem wiąże się następne, najbardziej, moim zdaniem, niepokojące zjawisko występujące $z$ wielką siłą w amerykańskiej ekspozycji. Chodzi o takie przedstawienie historii Zagłady, które podkreśla, że sama w sobie stanowiła ona negację wartości amerykańskich. Michael Berenbaum pisze: „w [tych] wydarzeniach widzimy naruszenie każdej kluczowej wartości amerykańskiej”39. Brutalność „innych” jest jednocześnie przerażająca i pocieszająca. To straszne widzieć, co zrobili, ale ich „inność” umacnia amerykańską tożsamość jako „wyzwolicieli”. Mamy tu zatem do czynienia z lekcją o zagrożeniach, które niesie ze sobą dyskryminacja, a wystawa staje się z jednej strony ostrzeżeniem, a z drugiej potwierdzeniem słuszności amerykańskich wartości. Ma również stanowić dowód na historyczność wydarzenia, a widzów zmienić ze zwykłej publiczności muzealnej w świadków historii ${ }^{40}$.

Wykorzystanie Holokaustu jako lekcji demokratyzacji i tolerancji dla szerokiej publiczności jest nie tylko etycznym nadużyciem, ale również szeroko otwiera drogę kiczowi występującemu tu w funkcji pedagogicznej. „Kicz jest [...] zasadniczo estetycznym systemem komunikacji masowej” - pisze Moles - i ma w tym wymiarze pewne pozytywne skutki, gdyż „umożliwia [społeczeństwu - A. Z.-W.] osiągnięcie wyższych wymagań, a także przejście od sentymentalizmu do wrażliwości”41. Jednak taka edukacja odbywa się poprzez stosowanie pewnych utartych schematów i uproszczeń, co w pewnych sytuacjach może mieć swoje konsekwencje. Gary Weissman,

${ }^{38}$ Ibidem, s. 38 .

${ }^{39}$ M. Berenbaum, The World Must Know. The History of The Holocaust as Told in the United States Holocaust Memorial Museum, Boston-Toronto-London 1993, s. 2.

${ }^{40}$ T. Cole, op. cit., s. 159-160.

${ }^{41}$ A. Moles, op. cit., s. 83. 
pisząc o niebezpieczeństwach grożących reprezentacjom Holokaustu, podzielił je na trzy podstawowe typy: trywializacja (wykorzystanie dla celów politycznych), „osłodzenie” (optymistyczne zakończenie, podkreślanie męczeństwa, bohaterstwa, ocalenia, zbawienia, triumfu ducha nad bestialstwem) oraz uniwersalizacja (traktowanie Zagłady w kategoriach symbolu lub archetypu skrajnego zła lub skrajnego cierpienia) ${ }^{42}$. Wydaje się, że przekształcanie tych wydarzeń w „ćwiczenie obywatelskości” grozi pojawieniem się w reprezentacji wszystkich trzech powyższych kategorii.

Saul Friedländer w jednej ze swoich prac zdefiniował specjalny rodzaju kiczu pojawiający się w wyobrażeniach zagłady, apokalipsy i śmierci. Według niego w „zwykłym” kiczu istnieje ekwiwalencja pomiędzy rzeczywistością a reprezentacją (gdy np. krajobraz na pocztówce przypomina prawdziwy krajobraz). Jednak w przypadku kiczu śmierci łączą się ze sobą dwa sprzeczne elementy: samotność i zgroza śmierci z odwołaniem do harmonii i emocjonalnej wspólnoty. Neutralizacja ekstremalnych sytuacji (na poziomie indywidualnego doświadczenia śmierć wywołuje autentyczne przerażenie), zamienianie ich w sentymentalną idyllę to, według Friedländera, jedna z cech charakterystycznych kiczu ${ }^{43}$. Badacz zauważa również istnienie stałej relacji identyfikującej nazizm ze śmiercią: nie realną śmiercią z jej codziennym horrorem i tragiczną banalnością, ale rytualną, wystylizowaną i estetyczną śmiercią, która chciałaby reprezentować horror, zniszczenie i potworność, ale ostatecznie pojawia się jako niebezpieczna i szkodliwa apoteoza ${ }^{44}$. Przedstawienie traumatycznych doświadczeń innych jest oczywiście problematyczne, gdyż nigdy nie mamy dostępu do wydarzenia „takiego, jakim rzeczywiście było”, jednak wydaje się, że pewnych niebezpieczeństw dałoby się uniknąć, chociażby nie „wtłaczając” zjawisk historycznych w pedagogiczne ramy czy nie nadając im sensu, którego same w sobie nie mają. Paradoksalnie świadczą o tym pewne elementy ekspozycji w Muzeum Holokaustu. Zaliczyłabym do nich „Wieżę twarzy” (Tower of Faces) - ekspozycję ponad tysiąca fotografii rodzinnych zrobionych między 1890 a 1941 rokiem w Ejszyszkach (niedaleko Wilna). We wrześniu 1941 roku żydowska społeczność Ejszyszek została wymordowana przez Einsatzgruppen, zdjęcia zaś ocaliła i ofiarowała muzeum urodzona tam i ocalona z Zagłady Yaffa Eliach. Fotografie umieszczone są w zwężającej się ku górze „wieży” przechodzącej przez wszystkie trzy kondygnacje ekspozycji. Patrząc na spokojne i radosne twarze ubranych $\mathrm{w}$ odświętne ubrania rodzin, znajdując mnóstwo podobieństw ze zdjęciami ze swoich własnych albumów i dodając do tego kontekst znany choćby jedynie z oglądanej właśnie wystawy, odwiedzający zdają sobie nagle sprawę, że „wieża jest w rzeczywistości kominem, album grobem, a upamiętnienie żałobą" 45 . W ten

${ }^{42}$ G. Weissman, Fantasies of Witnessing. Postwar Efforts to Experience the Holocaust, Ithaca-London 2004, s. 12.

${ }^{43}$ S. Friedländer, Reflections of Nazism. An Essay on Kitsch and Death, z franc. przeł. T. Weyr, Bloomington-Indianapolis 1993, s. 26-27.

${ }^{44}$ Ibidem, s. 43.

${ }^{45}$ M. Hirsch, Family Frames. Photography, Narrative and Postmemory, Cambridge-London 1997, s. 256. 
sposób w opowieść zostało włączone bogactwo życia sprzed Holokaustu. Zagłada nie oznacza tu jedynie fizycznego unicestwienia ludzi, ale całego ich życia, kultury i cywilizacji sprzed wojny. Stajemy w obliczu nieodwołalności tej straty i nie jesteśmy w stanie nadać jej jakiegokolwiek sensu, którego - co warto powiedzieć jeszcze raz - wydarzenia historyczne same w sobie nie mają.

Cele edukacyjne związane z propagowaniem tolerancji i ćwiczeniem obywatelskości nie powinny przesłaniać wydarzenia samego, gdyż oznacza to redukcję Holokaustu do lekcji ${ }^{46}$ służącej następnym pokoleniom i nadanie mu pedagogicznego znaczenia. Dodatkowo twórcy wystawy zdają się wierzyć, że lekcja ta jest nieodłączną częścią wydarzeń, wręcz w nich tkwi, trzeba ją tylko przekazać publiczności. Taka postawa - mimo najlepszych intencji twórców - upraszcza i schematyzuje wystawę „trudną” i zamienia ją w łatwe do zrozumienia moralne przesłanie. Muzeum Holokaustu zostało przez Leona Wieseltiera z „The New Republic” nazwane „pedagogicznym arcydziełem” 47 , ale mam poważne wątpliwości, czy powinniśmy uznać to za komplement.

\title{
Słowa kluczowe
}

Holokaust, reprezentacja, ekspozycja, kicz, pedagogika

\begin{abstract}
Museum exbibition is a medium consisting of multiple media but the whole is something more that the sum of its parts. Each exhibition is a kind of spectacle, a specific cultural creation, and it works according to its own rules. An exhibition is also the core of museum experience and, as such, it should be subject to multidimensional analysis. Meanwhile, the content of an exhibition and the material used in its construction are often assessed, and very little is said about it as a form of expression and the specific character of its influence on the public. In the article I analyze the exhibition in the United States Holocaust Memorial Museum in Washington in terms of the kitsch category. The term itself is hardly precise and it is multidimensional. Therefore I define it for the purposes of the and test to what extent it can be used to interpret goals and principles of assumptions behind historical exhibition dedicated to the Holocaust. The article is an exemplary interpretation of exhibition's poetics and policy and it aims at demonstrating how pedagogical functions of museum exhibitions about the Holocaust may reduce its dimension to a lesson on intolerance.
\end{abstract}

\section{Key words}

Holocaust, representation, exhibition, kitsch, pedagogy

${ }^{46}$ Według niektórych badaczy ekstremalność Holokaustu i skrajność warunków, w jakich był przeprowadzony, sprawia, że nie może on służyć celom pedagogicznym i być „lekcją” do zastosowania w codziennym świecie, patrz. P. Novick, The Holocaust in American Life, Boston - New York 1999, s. 244.

${ }^{47}$ J. Weinberg, R. Elieli, op. cit, s. 50. 